\title{
Value of colposcopy in sexually transmitted diseases clinic based on first year's experience
}

\author{
M A BYRNE, *§ D TAYLOR-ROBINSON, ${ }^{*} \S$ M A C ANDERSON, † P MASON, \\ J R.W HAR RIS* \\ From the *Jefferiss Research Wing of the Praed Street Clinic, the Departments of $\dagger$ Pathology and \\ $\ddagger$ Gynaecological Oncology, St Mary's Hospital, London, and the §Division of Sexually Transmitted Diseases, \\ Clinical Research Centre, Harrow, Middlesex
}

SUMMARY Two hundred and thirty two patients underwent cervical colposcopy within the first year of establishing a colposcopy service in the sexually transmitted diseases clinic at St Mary's Hospital, London. Their mean age was 27 years. Cervical intraepithelial neoplasia (CIN) was identified in 68 of $81(84 \%)$ patients whose smears showed dyskaryosis and who underwent biopsy. CIN was also detected in 14 of $41(34 \%)$ patients who underwent biopsy and whose repeat smears were reported as giving normal results. The value of assessing two consecutive smears was evident, however, because none of the 99 patients with CIN had two normal smear results consecutively. Patients requiring treatment underwent laser ablation, which was provided in the department of gynaecology. These results show that colposcopy plays a vital part in managing patients with abnormal smears and indicate that genitourinary physicians need to give priority to developing colposcopy services in their specialty.

Genitourinary physicians are aware of the increasing number of abnormal cervical smears being reported nationwide, especially in younger, nulliparous women, ' together with the prediction of a further rise in deaths from cervical cancer. ${ }^{2}$ Fatal disease can be prevented if the premalignant stages, namely cervical intraepithelial neoplasia (CIN), which have been well defined, are detected and treated. To this end, colposcopy with directed biopsy allows accurate localisation and histological diagnosis of the cervical lesion in most cases. In young women three quarters of such lesions are suitable for conservative local treatment that is easily undertaken in an outpatient clinic. ${ }^{3}$ Apart from this obvious requirement for colposcopy, several recent reports have highlighted the need to expand the indications for referral for colposcopy. ${ }^{45}$

The sexually transmitted diseases (STD) clinic at St Mary's Hospital is the largest of its kind in the United Kingdom and provides an open access service. In 1986 27500 visits by women were recorded, of which almost 6000 were by new patients. As many of the women attending the clinic are at risk of developing cervical

Address for reprints: Dr D Taylor-Robinson, Division of Sexually Transmitted Diseases, Clinical Research Centre, Watford Road, Harrow, Middlesex HAl 3UJ

Accepted for publication 13 July 1988

neoplasia, cervical cytological screening is undertaken unless there is evidence of a normal smear within the previous three years. About 4000 smear examinations are performed yearly, and $14 \%$ are reported to show abnormalities suggestive of CIN. To cope with the increasing demands for colposcopy and to provide rapid and easy access for patients, a diagnostic colposcopy clinic was set up within the STD clinic. In this communication, we report our observations during the first year on the diagnosis of disease in patients referred to the colposcopy clinic and on their management.

\section{Patients and methods}

The colposcopy clinic was held within the STD clinic. An Olympus colposcope and a separate case sheet with a standard form were used. Cervical smears and specimens for histology were processed by the department of pathology.

Patients were referred for colposcopy from the STD clinic for one or more of the following reasons: if they had an abnormal cervical smear report, genital warts, repeated technically unsatisfactory smears, or clinical indications that included an abnormal cervical appearance or intermenstrual or postcoital bleeding, or if they were participating in a research study. Patients were seen by appointment, allowing $30 \mathrm{~min}$ - 
Table 1 Predominant reason for colposcopy of 232 women

\begin{tabular}{lc}
\hline Indication & No (\%) of cases \\
\hline Abnormal smear: & \\
Dyskaryotic cells suggesting CIN & $88(38)$ \\
Borderline changes* & $95(41)$ \\
History of abnormal smear & $9(4)$ \\
Genital warts & $16(7)$ \\
Unsatisfactory smear & $8(3)$ \\
Clinical indication & $5(2)$ \\
Patient request & $11(5)$ \\
\hline
\end{tabular}

$\mathrm{CIN}=$ cervical intraepithelial neoplasia.

*Non-dyskaryotic atypical changes.

utes for new referrals. Cervical smears were taken in the usual way with an Ayre's spatula, and colposcopy was performed in a standard manner, colposcopic evaluations being recorded diagrammatically. The cervix was examined before and after the application of $3 \%$ acetic acid. Colposcopically directed biopsy specimens were taken using Tischler-Morgan forceps, and were fixed in Bouin's solution before being evaluated histologically. Schiller's test was then performed. When indicated clinically, specimens were taken for microbiological investigations.

Patients were counselled after their examination. It was possible to indicate to most at that time whether treatment was anticipated and to outline their further management. When the results of the investigations were available a decision was made for each patient and she was informed. Patients with histologically verified CIN, whose lesions were deemed suitable for local ablation, underwent laser treatment in the department of gynaecology. Patients with lesions not suitable for outpatient treatment and those requiring cone biopsy, were booked for admission for surgery. Other findings, such as genital tract infections, were managed appropriately.

\section{Results}

The observations were based on colposcopy undertaken on 232 women during the first year. The mean age of the patients was 27 (range 15 to 59) years, and
$193(83 \%)$ were 35 or younger. Table 1 shows the indications for referral for colposcopy, an abnormal smear result being the most common (in 183, 79\%). Many patients, however, had more than one indication, and $40(17 \%)$ underwent colposcopy for various reasons other than an abnormal smear report. Apart from the 88 patients who had dyskaryosis that suggested CIN, two of the eight patients whose smears were technically unsatisfactory were found to have CIN. Furthermore, of 16 patients with genital warts, histological examination of a cervical biopsy specimen showed that four had CIN and seven had infection with human papillomavirus. CIN was not detected in the remaining 16 patients who underwent colposcopy because it was clinically indicated or at their request. Fourteen patients underwent cone biopsy because of an unsatisfactory colposcopic examination, and they are excluded from the following results.

Smears for cytology were obtained from 159 women at the time of colposcopy, and table 2 shows how the results correlated with those of the initial smears. Of 90 women who had their initial atypical smears repeated, two thirds (58) continued to have either a technically unsatisfactory or persistently abnormal smear. Atypia was used to denote smears with minor abnormalities that were not sufficiently pronounced to be termed dyskaryotic.

Table 3 shows how the cytological findings at the time of colposcopy (repeat smears) correlated with the histological findings. Of 59 women with repeat smears reported as giving normal results, 41 were examined histologically. Twenty five $(61 \%)$ had an abnormal finding, with CIN being detected in 14 (34\%). Of 40 women with atypical repeat smear results who were examined histologically, $22(55 \%)$ had an abnormal finding, with CIN being detected in 15 (38\%). CIN occurred more often, however, in the 32 women with dyskaryotic smears; $27(84 \%)$ had an abnormal histological finding, with CIN being found in $22(69 \%)$. It is noteworthy that histological evidence of CIN was found most often (in 39/46, 85\%) in the group of women whose smears were not repeated because they

Table 2 Correlation between results of initial smears and repeat smears at colposcopy

\begin{tabular}{|c|c|c|c|c|c|c|c|c|}
\hline \multicolumn{2}{|l|}{ Initial smear } & \multicolumn{7}{|c|}{ Repeat smear } \\
\hline Description & No & $\begin{array}{l}\text { Not under- } \\
\text { taken }\end{array}$ & Normal & $\begin{array}{l}\text { Unsatis- } \\
\text { factory }\end{array}$ & Atypical* & $\begin{array}{l}\text { Mildly } \\
\text { dyskaryotic }\end{array}$ & $\begin{array}{l}\text { Moderately } \\
\text { dyskaryotic }\end{array}$ & $\begin{array}{l}\text { Severely } \\
\text { dyskaryotic }\end{array}$ \\
\hline $\begin{array}{l}\text { Not available } \\
\text { Normal } \\
\text { Unsatisfactory } \\
\text { Atypical* } \\
\text { Mildly dyskaryotic } \\
\text { Moderately dyskaryotic } \\
\text { Severely dyskaryotic }\end{array}$ & $\begin{array}{r}31 \\
3 \\
8 \\
101 \\
16 \\
22 \\
37\end{array}$ & $\begin{array}{r}4 \\
0 \\
0 \\
11 \\
8 \\
10 \\
26\end{array}$ & $\begin{array}{r}12 \\
2 \\
4 \\
32 \\
4 \\
4 \\
1\end{array}$ & $\begin{array}{r}0 \\
0 \\
3 \\
13 \\
0 \\
0 \\
1\end{array}$ & $\begin{array}{r}11 \\
1 \\
1 \\
34 \\
3 \\
1 \\
0\end{array}$ & $\begin{array}{l}2 \\
0 \\
0 \\
6 \\
0 \\
0 \\
2\end{array}$ & $\begin{array}{l}2 \\
0 \\
0 \\
5 \\
1 \\
5 \\
3\end{array}$ & $\begin{array}{l}0 \\
0 \\
0 \\
0 \\
0 \\
2 \\
4\end{array}$ \\
\hline Total & 218 & 59 & 59 & 17 & 51 & 10 & 16 & 6 \\
\hline
\end{tabular}

*Smears with abnormalities not sufficiently pronounced to be termed dyskaryotic. 
Table 3 Correlation between results of repeat smears at colposcopy and findings on histology

\begin{tabular}{|c|c|c|c|c|c|c|c|c|}
\hline \multicolumn{2}{|l|}{ Repeat smear } & \multicolumn{7}{|l|}{ Histology } \\
\hline Description & No & Not undertaken & Normal & Atypical* & Viral† & CIN I & CIN 2 & CIN 3 \\
\hline $\begin{array}{l}\text { Normal } \\
\text { Unsatisfactory } \\
\text { Atypical }^{*} \\
\text { Mildly dyskaryotic } \\
\text { Moderately dyskaryotic } \\
\text { Severely dyskaryotic } \\
\text { Not repeated }\end{array}$ & $\begin{array}{r}59 \\
17 \\
51 \\
10 \\
16 \\
6 \\
59\end{array}$ & $\begin{array}{r}18 \\
1 \\
11 \\
0 \\
0 \\
0 \\
13\end{array}$ & $\begin{array}{r}16 \\
1 \\
18 \\
3 \\
2 \\
0 \\
3\end{array}$ & $\begin{array}{l}1 \\
2 \\
3 \\
0 \\
1 \\
0 \\
1\end{array}$ & $\begin{array}{r}10 \\
4 \\
4 \\
1 \\
3 \\
0 \\
3\end{array}$ & $\begin{array}{l}6 \\
3 \\
9 \\
3 \\
4 \\
3 \\
6\end{array}$ & $\begin{array}{l}7 \\
4 \\
4 \\
3 \\
4 \\
0 \\
9\end{array}$ & $\begin{array}{r}1 \\
2 \\
2 \\
0 \\
2 \\
3 \\
24\end{array}$ \\
\hline Total & 218 & 43 & 43 & 8 & 25 & 34 & 31 & 34 \\
\hline
\end{tabular}

* = Abnormal changes insufficiently pronounced to indicate neoplasia.

$\dagger=$ Histological features suggesting human papillomavirus infection.

$\mathrm{CIN}=$ cervical intraepithelial neoplasia grades 1,2 , or 3 .

had shown a severe abnormality originally.

Table 4 shows the correlation between the histological findings and the most severe cytological abnormality detected in either smear. Of the 80 women whose most severe cytological abnormality was reported as atypia and who had a histological examination, $28(35 \%)$ had CIN. Of the 81 women whose smears showed dyskaryosis and who underwent histology, however, not all had CIN, this being detected in 68 $(84 \%)$. On the other hand, none of the 99 patients with CIN had two normal smears.

\section{Discussion}

Colposcopy plays a vital part in managing patients with cervical neoplasia and is becoming increasingly used in managing other cervical and genital tract disorders. Our observations highlight the value of colposcopy in a STD clinic setting where many women are at high risk of developing cervical neoplasia and a disproportionately large number of cervical smears are reported as giving abnormal results. We noted a considerable difference between the cytological findings in cervical smears made at the time of colposcopy and the histological findings. Thus CIN was found histologically in $34 \%$ of women whose repeat smears were reported as being normal. Singer et $\mathrm{al}^{6}$ and Kitchener et al ${ }^{7}$ reported similar findings in $20 \%$ and $11 \%$ of their patients, respectively. On the other hand, of women in our study whose repeat smears contained dyskaryotic cells suggestive of CIN, only $16 \%$ had no histological abnormality. This figure compares favourably with those of $15 \%$ and $20 \%$ reported in other studies. ${ }^{67}$ The value of assessing two smears became evident from the fact that the discrepancy between cytological and histological features diminished when the most severe cytological abnormality was selected from either smear and compared with the presence of CIN. Indeed, on this basis none of the patients with CIN had a normal cytological smear result. An histological abnormality was not confirmed, however, or the cervix appeared normal colposcopically in about one sixth of the patients whose smears were dyskaryotic at any time. This might be explained by regression of the lesion or the correct site not having been biopsied. As further colposcopic experience is gained the latter possibility should decrease. Follow up of patients whose cytological and histological results are at variance or whose cytological results are not consistent is essential. A

Table 4 Correlation between most severe cytological abnormality at any time and findings on histology

\begin{tabular}{|c|c|c|c|c|c|c|c|c|}
\hline \multicolumn{2}{|l|}{ Either smear } & \multicolumn{7}{|l|}{ Histology } \\
\hline Description & No & Not undertaken & Normal & Atypical* & Viral† & $C I N I$ & $C I N 2$ & $C I N 3$ \\
\hline $\begin{array}{l}\text { Not available } \\
\text { Normal } \\
\text { Unsatisfactory } \\
\text { Atypical* } \\
\text { Mildly dyskaryotic } \\
\text { Moderately dyskaryotic } \\
\text { Severely dyskaryotic }\end{array}$ & $\begin{array}{r}18 \\
2 \\
7 \\
102 \\
23 \\
27 \\
39\end{array}$ & $\begin{array}{r}3 \\
9 \\
1 \\
22 \\
5 \\
3 \\
0\end{array}$ & $\begin{array}{r}0 \\
2 \\
0 \\
34 \\
5 \\
1 \\
1\end{array}$ & $\begin{array}{l}0 \\
1 \\
0 \\
5 \\
1 \\
1 \\
0\end{array}$ & $\begin{array}{r}1 \\
5 \\
0 \\
13 \\
2 \\
4 \\
0\end{array}$ & $\begin{array}{r}0 \\
0 \\
1 \\
13 \\
5 \\
9 \\
6\end{array}$ & $\begin{array}{r}0 \\
0 \\
1 \\
11 \\
6 \\
5 \\
8\end{array}$ & $\begin{array}{r}0 \\
0 \\
1 \\
4 \\
0 \\
5 \\
24\end{array}$ \\
\hline Total & 218 & 43 & 43 & 8 & 25 & 34 & 31 & 34 \\
\hline
\end{tabular}

* = Abnormal changes insufficiently pronounced to indicate neoplasia.

$\dagger=$ Histological features suggesting human papillomavirus infection.

CIN = cervical intraepithelial neoplasia grades 1,2 , or 3 . 
normal smear after a dyskaryotic one does not exclude CIN and, conversely, patients with persistently dyskaryotic smears may require further investigation if colposcopy and biopsy give negative results.

The importance of undertaking colposcopy was further highlighted by the detection of CIN in $38 \%$ of patients whose repeat smears were reported as borderline (non-dyskaryotic atypical changes only). This figure is the same as that reported by Soutter et al in patients with similar cytological findings, ${ }^{4}$ and not out of line with an incidence of $29 \%$ reported by Walker et al. ${ }^{5}$ The detection of CIN changes in some patients by colpobiopsy, despite the failure to detect them even by examining two smears, suggests that additional colposcopy may be valuable in screening certain high risk groups. Furthermore, because of the increasing numbers of patients with HPV infections who attend STD clinics, and the fact that many cervical and penile HPV infections are subclinical and require colposcopic evaluation for their diagnosis, treatment, and follow up, ${ }^{89}$ ample justification exists for making colposcopy more widely available. The siting of colposcopic facilities within the STD clinic should help to improve the follow up of such patients, which is often inadequate. ${ }^{10}$ We conclude that genitourinary physicians need to give priority to developing colposcopy services in their specialty in anticipation of future increasing demands.
We thank Mrs Maura Lawlor for her assistance with the colposcopy and Mrs Kathy Jameson for typing the manuscript.

\section{References}

1 Draper GJ, Cook GA. Changing patterns of cervical cancer rates. Br Med J 1983;287:510-2.

2 Beral V, Booth M. Predictions of cervical cancer incidence and mortality in England and Wales. Lancet 1986;i:495.

3 Singer A, Walker $\mathbf{P}$. What is the optimum treatment of cervical premalignancy? Br J Obstet Gynaecol 1982;89:335-37.

4 Soutter WP, Wisdom S, Brough AK, Monaghan JM. Should patients with mild atypia in a cervical smear be referred for colposcopy? Br J Obstet Gynaecol 1986;93:70-4.

5 Walker EM, Dodgson J, Duncan ID. Does mild atypia on a cervical smear warrant further investigation? Lancet 1986; ii:672-3.

6 Singer A, Walker P, Tay SK, Dyson J. Impact of introduction of colposcopy in a district general hospital. Br Med J 1984; 289:1049-51.

7 Kitchener HC, Burnett RA, Wilson ESB, Cordiner JW. Colposcopy in a family planning clinic: a future model? $\mathrm{Br} \mathrm{Med} J$ 1987;294:1313-5.

8 Meisels A, Fortin R, Roy M. Condylomatous lesions of the cervix. II. Cytologic, colposcopic, and histopathologic study. Acta Cytol 1977;21:379-90.

9 Barrasso R, De Brux J, Croissant O, Orth G. High prevalence of papillomavirus-associated penile intraepithelial neoplasia in sexual partners of women with cervical intraepithelial neoplasia. N Engl J Med 1987;317:916-23.

10 Elwood JM, Cotton RE, Johnson J, Jones GM, Curnow J, Beaver MW. Are patients with abnormal smears adequately managed? Br Med J 1984;289:891-4. 